\title{
PERBEDAAN PENDAPATAN USAHATAN AREN (Arenga pinnata, Merr) DALAM BENTUK GULA CAIR DENGAN BENTUK GULA PADAT DI KECAMATAN SUNGAI RAYA KABUPATEN ACEH TIMUR
}

\author{
Ir. Hanisah, MP1/Ahmad Fauzi ${ }^{2}$ \\ ${ }^{1}$ Dosen Tetap Program Studi Agribisnis Fakultas Pertanian \\ ${ }^{2}$ Mahasiswa Fakultas Pertanian Program Studi Agribisnis \\ Universitas Samudra, Langsa-Aceh
}

\begin{abstract}
ABSTRAK
Adapun tujuan dari penelitian ini adalah untuk mengetahui perbedaan pendapatan usahatani aren dalam bentuk gula cair dengan bentuk gula padat. Penelitian ini dilakukan dengan menggunakan metode survey. Pengambilan petani sampel dilakukan dengan menggunakan metode Simple Random Sampling (acak sederhana) dengan pengambilan sampel yang memberikan peluang yang sama bagi setiap unure (anggota) populasi menjadi anggota sampel, baik dari usahatani aren yang diproduksikan dalam bentuk gula cair maupun dalam bentuk gula padat. Jumlah petani sampel pada usahatani aren dalam bentuk gula Padat dan bentuk gula cair adalah 26 orang.

Hasil penelitian rata-rata luas lahan garapan untuk tanaman aren petani yang menjual dalam bentuk gula cair adalah $0.046 \mathrm{Ha}$ dan bentuk gula padat adalah $0.062 \mathrm{Ha}$. Rata-rata Penggunaan tenaga kerja aren dalam bentuk gula cair untuk tenaga kerja dalam keluarga 7.21 HKP/UT atau 148.14 HKP/Ha. Penggunaan tenaga kerja aren yang menjual dalam bentuk gula padat untuk tenaga kerja dalam keluarga 10.32 HKP/UT atau 167.25 HKP/Ha.Pada usahatani aren perbedaan penggunaan biaya produksi usahatani aren bentuk gula cair dan bentuk gula padat adalah Rp. 142.010,47/UT dan Rp. 798.522,48/Ha atau 21.5\%.

Rata-rata produksi aren bentuk gula cair dengan bentuk gula padat dengan selisih nilai produksinya adalah Rp. 76.740,00/UT dan Rp. 648.864,33/Ha atau 10,34\%. Rata-rata pendapatan bersih usahatani aren dengan Selisih pendapatan usahatani aren bentuk gula cair dengan bentuk gula padat adalah Rp. 34.736,67/UT atau Rp. 1.447.276,63/Ha atau 48,38\%.

Dari hasil perhitungan perbedaan pendapatan usahatani aren bentuk gula cair dan bentuk gula padat diperoleh t hitung $=2,816$ sedangkan t tabel pada tingkat kepercayaan $95 \%(\alpha=0,05)$ dengan $\mathrm{dk}=14+12-2$ $=24$ adalah 1,710 dan pada tingkat kepercayaan 99\% $(\alpha=0,01)$ dengan dk=14 $+12-2=24$ adalah 2,492. Ini berarti $t$ hitung $>t$ tabel baik pada tingkat kepercayaan $95 \%(\alpha=0,05)$ maupun pada tingkat kepercayaan 99\% $(\alpha=0,01)$. Dengan demikian maka hipotesis Ha diterima dan Ho ditolak. Artinya ada perbedaan pendapatan antara usahatani aren bentuk gula cair dengan bentuk gula padat di Kecamatan Sungai Raya Kabupaten Aceh Timur.
\end{abstract}

Kata Kunci: Aren, Gula Cair, Gula Padat, Pendapatan

\section{PENDAHULUAN}

Aren (Arenga pinnata, Merr) adalah palma yang terpenting setelah kelapa (nyiur) karena merupakan tanaman serba guna. Bangsa Belanda mengenalnya sebagai arenpalm atau zuikerpalm dan bangsa Jerman menyebutnya zuckerpalme. Dalam bahasa Inggris disebut sugar palm atau Gomutipalm (Slamet Soeseno,1992 : 48).

Gula aren merupakan produk agroindustri yang diproduksi oleh industriindustri kecil atau industri rumah tangga (home industry) yang umumnya berada di pedesaan. Proses pembuatan gula aren tersebut biasanya dilakukan secara tradisional dan menggunakan peralatan sederhana, jumlah produk yang dihasilkan terbatas. Untuk peningkatan nilai tambah pembuatan gula aren oleh industri rumah tangga.

Gula aren diperoleh dengan menyadap tandan bunga jantan yang mulai mekar dan menghamburkan serbuk sari yang berwarna kuning. Tandan ini mula-mula dimemarkan dengan memukul-mukulnya selama beberapa hari, hingga keluar cairan dari dalamnya. Tandan kemudian dipotong dan diujungnya digantungkan tahang bambu untuk menampung cairan yang menetes. Cairan manis yang diperoleh dinamai nira (alias legen atau saguer), berwarna jernih agak keruh. Nira ini tidak tahan lama, maka tahang bambu yang telah berisi harus segera diambil untuk diolah niranya, biasanya sehari dua kali pengambilan yakni pagi dan sore. Setelah dikumpulkan nira segera dimasak hingga mengental dan menjadi gula cair. Selanjutnya, dalam gula cair ini dapat dibubuhkan bahan pengeras (misalnya campuran buah kemiri dengan beberapa bahan lain) agar gula membeku dan dapat dicetak menjadi gula aren bongkahan (gula gandu) atau dibiarkan menjadi bentuk gula cair saja.

Kebutuhan masyarakat terhadap gula aren dalam bentuk gula padat dengan gula aren dalam bentuk cair sama tingginya, karena memiliki kegunaan yang sama untuk proses pembuatan kue, akan tetapi gula aren dalam bentuk cair banyak diproduksi untuk pengusaha . Sedangkan masyarakat lebih banyak memilih gula aren dalam bentuk padat karena lebih mudah penyimpanannya dan tahan lebih lama dibandingkan dengan gula aren dalam bentuk cair.

Air aren termasuk tanaman hasil pertanian yang bernilai ekonomis tinggi, untuk 
meningkatkan nilai tambahnya air nira dapat diolah menjadi bentuk gula cair dan bentuk gula padat agar tahan lama. Air nira merupakan makanan yang sangat bergizi karena mengandung air dan karbohidrat yang tinggi.

Di Kabupaten Aceh Timur para petani aren memproduksi gula aren dalam bentuk cair dan padat. Permintaan gula aren sebagai bahan makanan pengganti gula pasir dan pemanis buatan ini menyebabkan aren menjadi komoditi andalan bagi para petani aren.

Peningkatan permintaan gula aren di masyarakat merupakan peluang utama bagi para petani untuk berupaya meningkatkan pendapatannya. Peningkatan pendapatan dilakukan dengan melakukan penambahan nilai atau harga gula aren. Harga gula aren dalam bentuk gula padat berbeda dengan harga gula aren dalam bentuk gula cair.

Tabel I-2: Luas Lahan, Produksi dan Produktivitas Usahatani Aren di Kabupaten Aceh Timur, 2013

\begin{tabular}{|c|c|c|c|c|c|c|c|}
\hline \multirow{2}{*}{ No } & \multirow{2}{*}{ Kecamatan } & \multicolumn{3}{|c|}{ Luas Areal (Ha) } & \multirow{2}{*}{$\begin{array}{l}\text { Jumlah } \\
(\mathrm{Ha})\end{array}$} & \multirow{2}{*}{$\begin{array}{l}\text { Produksi } \\
\text { (Ton) }\end{array}$} & \multirow{2}{*}{$\begin{array}{l}\text { Produktivitas } \\
\text { (Ton/Ha) }\end{array}$} \\
\hline & & TBM & TM & TR & & & \\
\hline 1 & Serbajadi & 0,50 & 6,00 & 0,50 & 7,00 & 3,01 & 0,501 \\
\hline 2 & Rantau Peureulak & 0,50 & 2,25 & 0,25 & 3,00 & 1,13 & 0,502 \\
\hline 3 & Pante Bidari & 2,50 & 18,00 & 0.50 & 21,00 & 9,00 & 0,500 \\
\hline 4 & Sungai Raya & 0,20 & 6,80 & - & 7,00 & 3,91 & 0,575 \\
\hline 5 & Dahrul Ihsan & 0,20 & 1,80 & - & 2,00 & 0,90 & 0,400 \\
\hline 6 & Simpang Jernih & 2,00 & 6,00 & 0,50 & 8,50 & 3,30 & 0,550 \\
\hline 7 & Peunaron & 1,00 & 7,00 & - & 8,00 & 3,96 & 0,565 \\
\hline & Jumlah & 6,90 & 47,85 & 1,75 & 56,50 & 23,12 & 3,573 \\
\hline & Rata-Rata & 0,98 & 6,83 & 0,25 & 8,07 & 3,30 & 0,510 \\
\hline
\end{tabular}

Sumber : Dinas Kehutanan dan Perkebunan Kabupaten Aceh Timur, 2014

Dari Tabel I-2 di atas menunjukkan bahwa luas areal perkebunan aren bervariasi antara daerah yang satu dengan daerah yang lain, dimana luas daerah perkebunan aren seluruhnya adalah 56,5 hektar, dengan tingkat
Para petani aren di Kabupaten Aceh Timur menginginkan pendapatannya meningkat, sehingga mereka perlu mengetahui perbedakan pendapatan antara produk gula aren dalam bentuk gula padat dengan gula cair. Hal ini terlebih lagi potensi untuk komoditi aren di Kabupaten Aceh Timur yang sangat baik.

Kabupaten Aceh Timur memiliki 24 kecamatan, dari 24 kecamatan tersebut terdapat 7 kecamatan yang ada perkebunan aren. Kecamatan Sungai Raya merupakan salah satu kecamatan yang berada dalam wilayah Kabupaten Aceh Timur yang sebagian penduduknya berprofesi sebagai petani aren. Untuk mengetahui luas lahan, produksi dan produktivitas usahatani aren di Kabupaten Aceh Timur dapat dilahat pada tabel I-2 berikut:

Tabel I-3 : Keadaan Luas Areal, Produksi dan Produktivitas Uasahatani Aren di Kecamatan Sungai Raya, 2013

\begin{tabular}{|l|l|r|r|r|r|}
\hline No & \multicolumn{1}{|c|}{ Desa } & $\begin{array}{c}\text { Luas Tanam } \\
(\mathrm{Ha})\end{array}$ & $\begin{array}{c}\text { Luas Panen } \\
(\mathrm{Ha})\end{array}$ & $\begin{array}{c}\text { Produksi } \\
(\text { Ton })\end{array}$ & $\begin{array}{c}\text { Produktivitas } \\
(\text { Ton/Ha })\end{array}$ \\
\hline 1 & Alue Rangan & 0,28 & 0,23 & 0,20 & 0,86 \\
2 & Gelumpang Payong & 0,40 & 0,35 & 0,17 & 0,44 \\
3 & Labuhan Kede & 0,45 & 0,40 & 0,15 & 0,37 \\
4 & Kuala Parek & 0,25 & 0,20 & 0,10 & 0,50 \\
5 & Bukit Selamat & 0,50 & 0,45 & 0,23 & 0,51 \\
6 & Krung Lingka & 0,50 & 0,45 & 0,22 & 0,48 \\
7 & Bukit Drien & 1,20 & 1,15 & 0,60 & 0,43 \\
8 & Alue Itam & 0,65 & 0,59 & 0,40 & 0,67 \\
9 & Seuneumbok Pase & 0,80 & 0,74 & 0,55 & 0,74 \\
10 & Paya Ketapang & 0,30 & 0,25 & 0,30 & 1,20 \\
11 & Sungai Simpang & 0,79 & 0,75 & 0,50 & 0,66 \\
12 & Seuneumbok Aceh & 0,53 & 0,45 & 0,38 & 0,84 \\
13 & Gajah Meuntah & 0,35 & 0,30 & 0,20 & 0,66 \\
\hline \multicolumn{2}{|c|}{ Jumlah } & 7,00 & 6.80 & 3,91 & 8,36 \\
\hline
\end{tabular}

Sumber : BPP Kecamatan Sungai Raya, 2014

Tabel I-3 menunjukkan bahwa luas produksi seluruhnya adalah 23,21 ton dan tingkat produktivitasnya adalah 0,510 ton/ha.

Untuk lebih jelasnya mengenai keadaan luas areal, produksi dan produktivitas usahatani aren di Kecamatan Sungai Raya Kabubaten Aceh Timur dapat dilihat pada tabel I-3 berikut :

tanaman aren di Kecamatan Sungai Raya Kabupaten Aceh Timur adalah 7 hektar. Luas

areal tanaman tertinggi terdapat di Desa Bukit Drien yaitu $2 \mathrm{Ha}$ dengan luas panen 1,15 Ha, 
produksi 0,60Ton dan produktivitas 0,56 Ton/Ha.

Usahatani merupakan pertanian rakyat yang mengelola sumber daya secara efektif dan efisien memperoleh keuntungan yang tinggi. Dikatakan efektif apabila dapat mengalokasikan sumber daya yang mereka miliki sebaik-baiknya dan efisien bila dimanfaatkan sumber daya tersebut mengeluarkan output melebihi input. Jadi usahatani adalah sebagai organisasi dari alam yang diusahakan oleh petani, keluarga tani, lembaga atau badan usaha lainnya yang berhubungan dengan pertanian untuk memenuhi kebutuhan masyarakat.

Petani aren menjual produknya dalam bentuk gula merah padat memerlukan proses pemasakan yang lebih lama dan memerlukan bahan campuran (kemiri dan bahan lainnya) agar air aren yang sudah diproses menjadi gula padat. Petani aren yang menjual produknya dalam bentuk gula merah cair setelah proses penyadapan air aren, air aren dimasak sampai warna berubah menjadi kemerahan dan mengental. Perbandingan pendapatan antara gula aren dalam bentuk gula padat dan dalam bentuk gula cair tentu berbeda, dari segi harga gula aren dalam bentuk padat jauh lebih tinggi dibandingkan dengan gula aren dalam bentuk gula cair yaitu harga gula aren dalam bentuk padat sekitar Rp.18.000-20.000 / Kg. Sedangkan dalam bentuk gula cair harganya berkisar antara RP.14.000-16.000 / Kg.

Proses pembuatan gula merah dalam bentuk padat memerlukan tenaga kerja lebih banyak dibandingkan pembuatan gula merah dalam bentu cair. Tenaga yang digunakan usahatani aren dalam bentuk gula padat meliputi kegiatan : penyadapan, pemasakan dan penyetakan. Tenaga kerja yang digunakan usahatani aren dalam betuk gula cair meliputi kegiatan : penyadapan dan pemasakan air aren.

\section{Identifikasi Masalah}

Apakah ada perbedaan pendapatan usahatani aren dalam bentuk gula cair dengan usahatani aren dalam bentuk gula padat di Kecamatan Sungai Raya Kabupaten Aceh Timur".

\section{Hipotesis}

Ada perbedaan pendapatan usahatani aren dalam bentuk gula cair dan usahatani aren dalam bentuk gula padat di Kecamatan Sungai Raya Kabupaten Aceh Timur.

\section{METODE PENELITIAN}

Penelitian ini menggunakan metode survey. Menurut Sugiono (2012:6), "Metode survey digunakan untuk mendapatkan data dari suatu tempat tertentu yang alamiah (bukan buatan), tetapi peneliti melakukan perlakuan dalam pengumpulan data misalnya dengan mengedarkan kuesioner, test, wawancara terstruktur dan sebagiannya (perlakuan tidak seperti eksperimen)". Penentuan lokasi penelitian dilakukan dengan sengaja di Kecamatan Sungai Raya Kabupaten Aceh Timur dengan pertimbangan bahwa kecamatan tersebut merupakan daerah yang ada usahatani aren yang menjual produk dalam bentuk gula padat dan cair. Objek penelitian ini adalah usahatani aren yang memasarkan produknya dalam bentuk gula padat dan petani yang memasarkan produknya dalam bentuk gula cair.

Ruang lingkup penelitian meliputi biaya produksi, penerimaan, pendapatan dan produktivitas usahatani aren yang menjual dalam bentuk gula padat dengan gula cair. Penelitian dilaksanakan pada Bulan Maret sampai April 2015.

\section{Penentuan Sampel}

Kecamatan Sungai Raya terdapat 13 desa, dari 13 desa tersebut terdapat 7 desa yang ada usahatani aren yang diproduksi dalam bentuk gula cair dan dalam bentuk gula padat. Desa-desa tersebut adalah : Desa Alue Rangan, Desa Bukit Drien, Desa Alue Itam, Desa Seuneumbuk Pase, Desa Paya Keutapang, Desa Sungai Simpang dan Desa Seuneumbok Aceh. Ketujuh desa tersebut diambil sebagai desa sampel.

Pengambilan petani sampel dilakukan dengan menggunakan metode Simple Random Sampling (acak sederhana). Sugioyono (2010 : 82) menyatakan bahwa : "Simple Random Sampling adalah pengambilan sampel yang memberikan peluang yang sama bagi setiap unsure (anggota) populasi untuk menjadi anggota sampel". Pada penelitian ini pengambilan sampel diambil $20 \%$ dari jumlah populasi. Untuk lebih jelas dapat dilihat pada tabel II-1 berikut.

Tabel II-1 : Jumlah Petani Sampel Berdasarkan Desa Sampel di Kecamatan Sungai Raya, 2014

\begin{tabular}{|c|l|c|c|c|c|}
\hline No & \multicolumn{1}{|c|}{ Desa Sampel } & $\begin{array}{c}\text { Jumlah } \\
\text { Populasi } \\
\text { A }\end{array}$ & $\begin{array}{c}\text { Jumlah } \\
\text { Sampel } \\
\text { A }\end{array}$ & $\begin{array}{c}\text { Jumlah } \\
\text { Populasi } \\
\text { B }\end{array}$ & $\begin{array}{c}\text { Jumlah } \\
\text { Sampel } \\
\text { B }\end{array}$ \\
\hline 1 & Alue Rangan & 8 & 2 & 12 & 2 \\
2 & Paya Ketapang & 12 & 2 & 6 & 1 \\
3 & Sungai Simpang & 12 & 2 & 8 & 2 \\
4 & Seuneumbok Pase & 7 & 1 & 15 & 3 \\
5 & Alue Itam & 8 & 2 & 6 & 1 \\
6 & Buket Drien & 12 & 2 & 13 & 3 \\
7 & Seuneumbok Aceh & 7 & 1 & 10 & 2 \\
\hline & Jumlah & 64 & 12 & 70 & 14 \\
\hline
\end{tabular}

Sumber : Data primer (diolah), 2014

AGRISAMUDRA, Jurnal Penelitian Vol.2 No. 2 Juli-Desember 2015 
Keterangan :

\section{- A : Usahatani Aren Gula Cair}

B : Usahatani Aren Gula Padat

Tabel II-1 menunjukkan bahwa jumlah petani sampel pada usahatani aren dalam bentuk gula cair adalah Desa Alue Rangan 2 orang, Desa Paya Ketapang 2 orang, Desa Sungai Simpang 2 orang, Desa Seuneumbok Pase 1 oarang, Alue Itam 2 orang, Desa Buket Drien 2 orang dan Desa Seuneumbok Aceh 1 orang, sehingga jumlah seluruhnya 12 orang. Jumlah petani sampel pada usahatani aren dalam bentuk gula padat untuk Desa Alue Rangan 2 orang, Desa Paya Ketapang 1 orang, Desa Sungai Simpang 2 orang, Desa Seuneumbok Pase 3 oarang, Desa Alue Itam 1 orang, Desa Buket Drien 3 orang dan Desa Seuneumbok Aceh 2 orang, sehingga jumlah seluruhnya 14 orang.

Data yang dikumpulkan berupa data primer dan data sekunder. Data primer diperoleh dari wawancara langsung dengan responden dengan menggunakan daftar pertanyaan (quesioner), sedangkan data sekunder diperoleh dari Kantor Kecamatan dan instansi-instansi pemerintah lainnya serta ditunjang oleh literaturliteratur yang berhubungan erat dengan penelitian ini.

\section{Variabel dan Data yang Dianalisis}

Untuk menguji hipotesis yang telah diturunkan maka diperlukan beberapa variabel data, yaitu :

1. Tenaga kerja (HKP/Ha/Tahun)

2. Biaya produksi (Rp/Ha/Tahun)

3. Produksi (Kg/Ha/Tahun)

4. Harga produksi usahatani Aren

a. Harga produksi dalam bentuk gula cair (Rp/Kg)

b. Harga produksi dalam bentuk gula padat $(\mathrm{Rp} / \mathrm{Kg})$

5. Nilai produksi/pendapatan kotor (Rp/Ha/Tahun)

6. Pendapatan (Rp/Ha/Tahun)

bersih/keuntungan

\section{Metode Analisis dan Pengujian Hipotesis}

Data yang diperoleh dari lapangan baik data primer maupun data sekunder diolah dengan mentabulasikan dan kemudian dipindahkan ke dalam bentuk tabelaris sesuai dengan kebutuhan analisis.

Analisis Pendapatan

Pendapatan Kotor

Pendapatan kotor $=$ jumlah produksi $\mathrm{x}$ harga persatuan

$$
\mathrm{TR}=(\mathrm{Y}) \times(\text { Py }) \ldots \ldots . .(\text { Ken Suratiyah, } 2006: 65)
$$

Keterangan:

TR : Total penerimaan (Total Revenue)

Y : Produk yang diperoleh dalam usahatani
Py $\quad$ : Harga Y (Price)

Pendapatan Bersih

Pd $=$ TR - TC ..... ( Soekartawi, $1996: 58$ )

Keterangan :

$\mathrm{Pd} \quad$ : Pendapatan usahatani

TR : Penerimaan Total (total revenue)

TC : Biaya total (total cost)

Hipotesis yang telah diajukan, dianalisis dengan menggunakan statistik $u j i$ " $t$ " dengan rumus sebagai berikut:

$$
t_{\text {Hitung }}=\frac{\bar{X}_{1}-\bar{X}_{2}}{\sqrt{\frac{\left(n_{1}-1\right) S_{1}^{2}+\left(n_{2-1}\right) S_{2}^{2}}{n_{1}+n_{2}-2} \times \sqrt{\frac{1}{n_{1}}+\frac{1}{n_{2}}}}}
$$

Keterangan :

$$
\begin{aligned}
\bar{X}_{1} \text { dan } \bar{X}_{2}=\quad \begin{array}{l}
\text { Rata-rata pendapatan } \\
\text { usahatani aren dalam bentuk } \\
\text { gula cair dan rata-rata } \\
\text { pendapatan usahatani aren } \\
\text { dalam bentuk gula padat. }
\end{array} \\
S_{1}^{2} \text { dan } S_{2}^{2}=\quad \begin{array}{l}
\text { Rata-rata varian usahatani } \\
\text { aren dalam bentuk gula cair } \\
\text { dan bentuk gula padat. }
\end{array} \\
n_{1} \text { dan } n_{2}=\quad \begin{array}{l}
\text { Jumlah sampel petani aren } \\
\text { produksi dalam bentuk gula } \\
\text { cair dan gula padat. }
\end{array} \\
\text { Kaedah pengambilan keputusan }
\end{aligned}
$$
sebagai berikut :

- Jika t hitung $\geq \mathrm{t}$ tabel maka terima Ha dan tolak Ho

- Jika $\mathrm{t}$ hitung $\leq \mathrm{t}$ tabel maka tolak Ha dan terima Ho

Kriteria pengambilan keputusan :

Ho: Tidak ada perbedaan pendapatan usahatani aren dalam bentuk gula cair dengan bentuk gula padat.

$\mathrm{Ha}$ : Ada perbedaan pendapatan usahatani aren dalam bentuk gula cair dengan bentuk gula Padat.

\section{HASIL DAN PEMBAHASAN}

\section{Karakteristik Petan}

Karakteristik petani yang dimaksud dalam penelitian ini meliputi: umur, pendidikan, pengalaman berusahatani aren dan jumlah tanggungan keluarga. Karakteristik petani merupakan salah satu unsur yang dapat mempengaruhi tingkat produksi sekaligus pendapatan.

Peranan petani dalam mengelola usahataninya mencakup semua aspek, sehingga dituntut adanya keahlian dan keterampilan yang erat hubungannya kepada pendidikan dan pengalaman bertani. Kesemua ini merupakan 
faktor-faktor yang sangat mempengaruhi tingkat produksi dan pendapatan yang ingin diperoleh petani.

Karakteristik petani sangat mempengaruhi tingkat pengelolaan usahatani, karena suatu usahatani yang baik menghendaki petani yang mengusahakan yang berumur produktif dan berpengalaman tinggi serta mempunyai tanggungan keluarga yang dapat membantu dalam proses usahatani yang

membantu dalam proses usahatani yang penelitian dapat dilihat pada tabel IV-I berikut:
Tabel IV-1 : Rata-rata Karakteristik Petani Sampel Gula Aren Dalam Bentuk Cair di Kecamatan Sungai Raya, 2015

\begin{tabular}{|l|l|l|l|l|l|}
\hline No & Desa Sampel & $\begin{array}{l}\text { Umur } \\
\text { (Tahun) }\end{array}$ & $\begin{array}{l}\text { Pendidikan } \\
\text { (Tahun) }\end{array}$ & $\begin{array}{l}\text { Pengalaman } \\
\text { (Tahun) }\end{array}$ & $\begin{array}{l}\text { Tanggungan } \\
\text { (Orang) }\end{array}$ \\
\hline 1. & Alue Rangan & 48.50 & 9.00 & 16.00 & 3.50 \\
2. & Paya Ketapang & 45.00 & 6.00 & 10.00 & 3.00 \\
3. & Sungai Simpang & 40.00 & 7.50 & 14.00 & 4.00 \\
4. & Seuneumbok Pase & 40.00 & 12.00 & 15.00 & 6.00 \\
5 & Alue Itam & 47.50 & 9.00 & 18.50 & 7.00 \\
6 & Buket Drien & 47.50 & 6.00 & 21.00 & 3.00 \\
7 & Seuneumbok Aceh & 40.00 & 9.00 & 12.00 & 3.00 \\
\hline Jumlah & 537.00 & 96.00 & 181.00 & 51.00 \\
\hline \multicolumn{2}{|l|}{ Rata-Rata } & 44.75 & 8.00 & 15.08 & 4.25 \\
\hline
\end{tabular}

Sumber : Data Primer (diolah), 2015

Tabel IV-1 menunjukkan bahwa ratarata umur petani aren yang menjual dalam bentuk gula cair adalah 44.75 tahun, dengan masa pendidikan 8.00 tahun, pengalaman

Tabel IV-2 : Rata-rata Karakteristik Petani Sampel Gula Aren Dalam Bentuk Padat di Kecamatan Sungai Raya, 2015

\begin{tabular}{|l|l|l|l|l|l|}
\hline No & Desa Sampel & $\begin{array}{l}\text { Umur } \\
\text { (Tahun) }\end{array}$ & $\begin{array}{l}\text { Pendidikan } \\
\text { (Tahun) }\end{array}$ & $\begin{array}{l}\text { Pengalaman } \\
\text { (Tahun) }\end{array}$ & $\begin{array}{l}\text { Tanggungan } \\
\text { (Orang) }\end{array}$ \\
\hline 1. & Alue Rangan & 53.50 & 12.00 & 16.50 & 3.50 \\
2. & Paya Ketapang & 40.00 & 6.00 & 10.00 & 2.00 \\
3. & Sungai Simpang & 41.50 & 7.50 & 14.50 & 2.50 \\
4. & Seuneumbok Pase & 53.33 & 9.00 & 23.33 & 3.33 \\
5 & Alue Itam & 53.00 & 9.00 & 30.00 & 6.00 \\
6 & Buket Drien & 67.00 & 6.00 & 45.00 & 1.33 \\
7 & Seuneumbok Aceh & 53.50 & 7.00 & 14.00 & 2.50 \\
\hline Jumlah & 751.00 & 114.00 & 335.00 & 39.00 \\
\hline \multicolumn{2}{|l|}{ Rata-Rata } & 53.64 & 8.14 & 23.93 & 2.79 \\
\hline
\end{tabular}

Sumber : Data Primer (diolah) 2015

Tabel IV-2 menunjukkan bahwa ratarata umur petani aren yang menjual dalam bentuk padat adalah 53.64 tahun, dengan masa pendidikan 8,14 tahun, pengalaman berusahatani 23.93 tahun dan besarnya tanggungan keluarga 2 orang. dikerjakannya. Hal ini akan memberi pengaruh yang lebih besar terhadap pendapatan, bila dibandingkan dengan petani yang usianya lebih lanjut dan rendahnya pengalaman dalam berusahatani, serta tidak adanya tanggungan yang dapat membantu dalam kegiatan peningkatan produksi. Untuk lebih jelasnya mengenai keadaan karakteristik petani sampel usahatani aren bentuk gula cair di daerah penelitian dapat dilihat pada tabel IV-I berikut :

berusahatani 15.08 tahun dan besarnya tanggungan keluarga 4 orang.

Untuk melihat rata-rata karakteristik petani sempel gula aren bentuk gula padat dapat dilihat pada tebel IV-2 berikut :

\section{Luas Lahan Garapan}

Luas garapan yang dimaksud dalam penelitian ini adalah luas lahan yang dikelola petani aren yang diambil produknya dalam bentuk gula cair dan dalam bentuk gula padat. Rata-rata luas garapan petani sampel yang menjual dalam bentuk gula cair dan bentuk gula padat di Kecamatan Sungai Raya dapat dilihat pada tabel IV-3 berikut : 
Tabel IV-3 : Rata-Rata Luas Garapan Usahatani Aren Bentuk Gula Cair dan Bentuk Gula Padat di Kecamatan Sungai Raya, 2015

\begin{tabular}{|l|l|l|ll|}
\hline \multirow{2}{*}{ No } & \multirow{4}{|l|}{ Luas Lahan Garapan (Ha) } \\
& Desa Sampel & $\begin{array}{l}\text { Usahatani Aren Bentuk Gula } \\
\text { Cair }\end{array}$ & $\begin{array}{l}\text { Usahatani Aren Bentuk } \\
\text { Gula Padat }\end{array}$ & \\
\hline 1. & Alue Rangan & 0.053 & 0.060 \\
2. & Paya Keutapang & 0.045 & 0.050 \\
3. & Sungai Simpang & 0.058 & 0.065 \\
4. & Seuneumbok Pase & 0.065 & 0.067 \\
5 & Alue Itam & 0.048 & 0.060 \\
6 & Buket Drien & 0.060 & 0.066 & \\
7 & Seuneumbok Aceh & 0.060 & 0.053 & \\
\hline \multicolumn{2}{|l|}{ Jumlah } & 0.650 & 0.864 & \\
\hline \multicolumn{2}{|l|}{ Rata-Rata } & 0.046 & 0.062 & \\
\hline
\end{tabular}

Sumber : Data Primer (diolah), 2015

Tabel IV-3 diatas menunjukkan bahwa rata-rata luas garapan untuk tanaman aren yang menjual produknya dalam bentuk gula cair adalah $0.046 \mathrm{Ha}$ dan bentuk gula cair adalah $0.062 \mathrm{Ha}$.

\section{Penggunaan Tenaga Kerja}

Tenaga kerja yang digunakan usahatani aren dalam bentuk gula cair meliputi kegiatan : penyadapan dan pemasakan air aren. Tenaga kerja yang digunakan pada usahatani aren dalam bentuk gula padat meliputi kegiatan : penyadapan, pemasakan dan penyetakan. Penggunaan tenaga kerja di daerah penelitian seluruhnya Tenaga kerja yang digunakan usahatani aren dalam bentuk gula cair meliputi kegiatan : penyadapan dan pemasakan air aren. Tenaga kerja dalam keluarga. Hal ini disebabkan karena rata-rata luas lahan usahatani aren di daerah penelitian tidak terlalu luas. Untuk setiap fase kegiatan usahatani aren dalam bentuk gula cair dan bentuk gula padat dapat dilihat pada tabel IV-4 berikut:

Tabel IV-4 : Rata-Rata Penggunaan Tenaga Kerja Usahatani Aren yang Menjual Produk Dalam Bentuk Gula Cair dan Bentuk Gula Padat di Kecamatan Sungai Raya, 2015

\begin{tabular}{|c|c|c|c|c|c|}
\hline \multirow{3}{*}{ No } & \multirow{3}{*}{ Jenis Kegiatan } & \multicolumn{4}{|c|}{ Penggunaan Tenaga Kerja (HKP) } \\
\hline & & \multicolumn{2}{|c|}{ Gula Padat } & \multicolumn{2}{|c|}{ Gula cair } \\
\hline & & Per-UT & Per-Ha & Per-UT & Per-Ha \\
\hline 1. & Pembersihan Lahan & 1.96 & 40.52 & 2.21 & 35.88 \\
\hline 2. & Penyadapan & 1.96 & 40.52 & 2.21 & 35.88 \\
\hline 3. & Pemasakan & 2.83 & 58.62 & 4.14 & 67.13 \\
\hline 4. & Pencetakan & - & - & 0.75 & 12.15 \\
\hline 5. & Pengepakan & 0.46 & 9.48 & 1.00 & 16.20 \\
\hline \multicolumn{2}{|c|}{ Jumlah } & 7.21 & 149.14 & 10.32 & 167.25 \\
\hline
\end{tabular}

Sumber : Data Primer (diolah), 2015

Tabel IV-4 di atas menunjukkan bahwa rata-rata penggunaan tenaga kerja aren dalam bentuk gula cair 7.21 HKP/UT atau 149.14 $\mathrm{HKP} / \mathrm{Ha}$. Penggunaan tenaga kerja yang menjual dalam bentuk gula padat $10.32 \mathrm{HKP} / \mathrm{UT}$ atau 167.25 HKP/Ha.

\section{Biaya Produksi}

Biaya produksi dalam penelitian ini terbagi atas dua jenis, yaitu biaya tetap (fixed cost) adalah biaya yang besarnya tidak tergantung dengan besar kecilnya produksi dan biaya variabel (variable cost) adalah biaya yang besarnya tergantung dengan besar kecilnya produksi.

Biaya tetap terdiri dari biaya sewa lahan dan biaya penyusutan alat yang dipergunakan seperti parang, wajan, pisau dan lain-lain, baik yang dibayar tunai maupun tidak tunai tetapi diperhitungkan. Biaya variabel terdiri biaya kemiri dan biaya tenaga kerja. Untuk melihat total biaya produksi yang dikeluarkan petani dalam satu tahun dalam bentuk gula cair dilihat pada tabel IV-5 berikut: 
Tabel IV-5 : Rata-rata Penggunaan Biaya Produksi Usahatani Aren Bentuk Gula Cair di Kecamatan Sungai Raya, 2015

\begin{tabular}{|l|l|l|l|l|c|}
\hline \multirow{2}{*}{ No. } & \multirow{2}{*}{ Jenis Biaya } & \multicolumn{4}{|c|}{ Jumlah Biaya Produksi } \\
\cline { 3 - 6 } & & \multicolumn{2}{|c|}{ Biaya Tetap (Rp) } & \multicolumn{2}{c|}{ Biaya Variabel (Rp) } \\
\cline { 3 - 6 } & & Per-UT & Per-Ha & Per-UT & Per-Ha \\
\hline 1. & Alue Rangan & $361.680,00$ & $6.889 .142,86$ & $160.000,00$ & $3.047 .619,05$ \\
2. & Paya Keutapang & $324.180,00$ & $7.204 .000,00$ & $160.000,00$ & $3.555 .555,56$ \\
3. & Sungai Simpang & $386.680,00$ & $6.724 .869,57$ & $170.000,00$ & $2.956 .521,74$ \\
4. & Seuneumbok Pase & $424.180,00$ & $6.525 .846,15$ & $180.000,00$ & $2.769 .230,77$ \\
5. & Alue Itam & $336.680,00$ & $7.088 .000,00$ & $160.000,00$ & $3.368 .421,05$ \\
6. & Bukit Drien & $399.180,00$ & $6.653 .000,00$ & $180.000,00$ & $3.000 .000,00$ \\
7. & Seuneumbok Aceh & $299.180,00$ & $7.479 .500,00$ & $160.000,00$ & $4.000 .000,00$ \\
\hline \multicolumn{2}{|l|}{ Rata-rata } & $361.680,00$ & $6.889 .142,86$ & $166.666,67$ & $3.174 .603,17$ \\
\hline
\end{tabular}

Sumber : Data Primer (diolah), 2015

Tabel IV-5 di atas menunjukkan pada usahatani aren dalam bentuk gula cair rata-rata penggunaan biaya produksi tetap adalah $\mathrm{Rp}$. 361.680,00/UT atau Rp. 6.889.142,86/Ha.

Sedangkan penggunaan biaya variabel adalah Rp. 166.666,67/UT atau Rp. 3.174.603,17/Ha. Untuk melihat rata-rata total penggunaan biaya produksi aren dalam bentuk gula cair dapat di lihat pada tabel IV-6 berikut:

Tabel IV-6 : Rata-rata Total Penggunaan Biaya Produksi Usahatani Aren Bentuk Gula Cair di Kecamatan Sungai Raya, 2015

\begin{tabular}{|l|l|l|l|}
\hline \multirow{2}{*}{ No. } & \multicolumn{1}{|c|}{ Jenis Biaya } & \multicolumn{2}{|c|}{ Jumlah Biaya Produksi Total (Rp) } \\
\cline { 3 - 4 } & & \multicolumn{1}{|c|}{ Per-UT } \\
\hline 1. & Alue Rangan & $521.680,00$ & \multicolumn{1}{c|}{ Per } \\
2. & Paya Keutapang & $484.180,00$ & $10.759 .555,56,56$ \\
3. & Sungai Simpang & $556.680,00$ & $9.681 .391,30$ \\
4. & Seuneumbok Pase & $604.180,00$ & $9.295 .076,92$ \\
5. & Alue Itam & $496.680,00$ & $10.456 .421,05$ \\
6. & Bukit Drien & $579.180,00$ & $9.653 .000,00$ \\
7. & Seuneumbok Aceh & $459.180,00$ & $11.479 .500,00$ \\
\hline \multicolumn{2}{|l|}{ Rata-rata } & $528.346,67$ & $10.063 .746,07$ \\
\hline
\end{tabular}

Sumber : Data Primer (diolah), 2015

Tabel IV-6 di atas menunjukka pada usahatani aren bentuk gula cair rata-rata total penggunaan biaya produksi usahatani aren bentuk gula cair adalah Rp. 528.346,67/UT atau Rp. 10.063.746,07/Ha.

Tabel IV-7 : Rata-rata Penggunaan Biaya Produksi Usahatani Aren Bentuk Gula padat di Kecamatan Sungai Raya, 2015

\begin{tabular}{|l|l|c|c|c|c|}
\hline \multirow{2}{*}{ No. } & \multirow{2}{*}{ Jenis Biaya } & \multicolumn{4}{|c|}{ Jumlah Biaya Produksi } \\
\cline { 3 - 6 } & & \multicolumn{2}{|c|}{ Biaya Tetap (Rp) } & \multicolumn{2}{c|}{ Biaya Variabel (Rp) } \\
\cline { 3 - 6 } & & Per-UT & Per-Ha & Per-UT & Per-Ha \\
\hline 1. & Alue Rangan & $442.600,00$ & $7.376 .666,67$ & $218.500,00$ & $3.641 .666,67$ \\
2. & Paya Keutapang & $387.650,00$ & $7.753 .000,00$ & $203.500,00$ & $4.070 .000,00$ \\
3. & Sungai Simpang & $467.600,00$ & $7.193 .846,15$ & $234.500,00$ & $3.607 .692,31$ \\
4. & Seuneumbok Pase & $472.700,00$ & $7.090 .500,00$ & $224.500,00$ & $3.367 .500,00$ \\
5. & Alue Itam & $441.650,00$ & $7.360 .833,33$ & $203.500,00$ & $3.391 .666,67$ \\
6. & Bukit Drien & $473.000,00$ & $7.130 .653,27$ & $231.500,00$ & $3.489 .949,75$ \\
7. & Seuneumbok Aceh & $405.100,00$ & $7.716 .190,48$ & $203.500,00$ & $3.876 .190,48$ \\
\hline \multicolumn{2}{|r|}{ Rata-rata } & $449.785,71$ & $7.288 .194,44$ & $220.571,43$ & $3.574 .074,07$ \\
\hline
\end{tabular}

Sumber : Data Primer (diolah), 2015

Tabel IV-7 di atas menunjukkan usahatani aren bentuk gula padat rata-rata penggunaan biaya produksi tetap adalah Rp. 449.785,71/UT atau Rp. 7.288.194,44/Ha.
Sedangkan biaya variabel adalah Rp. 220.571,43/UT atau Rp. 3.574.074,07/Ha Untuk melihat rata-rata total penggunaan biaya produksi aren dalam bentuk gula padat dapat di lihat pada tabel IV-8 berikut: 
Tabel IV-8 : Rata-rata Total Penggunaan Biaya Produksi Usahatani Aren Bentuk Gula Padat di Kecamatan Sungai Raya, 2015

\begin{tabular}{|l|l|l|l|}
\hline \multirow{2}{*}{ No. } & \multirow{2}{*}{ Jenis Biaya } & Jumlah Biaya Produksi Total (Rp) \\
\cline { 3 - 4 } & & Per-UT & Per-Ha \\
\hline 1. & Alue Rangan & $661.100,00$ & $11.018 .333,33$ \\
2. & Paya Keutapang & $591.150,00$ & $11.823 .000,00$ \\
3. & Sungai Simpang & $702.100,00$ & $10.801 .538,46$ \\
4. & Seuneumbok Pase & $697.200,00$ & $10.752 .500,00$ \\
5. & Alue Itam & $645.150,00$ & $10.752 .500,00$ \\
6. & Bukit Drien & $704.500,00$ & $10.620 .603,02$ \\
7. & Seuneumbok Aceh & $608.600,00$ & $11.592 .380,95$ \\
\hline \multicolumn{2}{|l|}{ Rata-rata } & $670.357,14$ & $10.862 .268,52$ \\
\hline
\end{tabular}

Sumber : Data Primer (diolah) 2015

Tabel IV-8 di atas menunjukkan usahatani aren bentu gula padat rata-rata total penggunaan biaya produksi usahatani aren bentuk padat adalah Rp. $670.357,14 /$ UT atau Rp. 10.862.268,52/Ha. Perbedaan penggunaan biaya produksi usahatani aren bentuk gula cair dan bentuk gula padat adalah $\mathrm{Rp}$. 142.010,47/UT dan Rp. 798.522,48/Ha atau $21,18 \%$.

\section{Produksi dan Nilai Produksi}

Produksi adalah hasil dari balas jasa akibat penggunaan ataupun pemanfaatan Tabel IV-9 : Rata-rata Produksi dan Nilai Produksi Usahatani Aren Bentuk Gula Cair di Kecamatan Sungai Raya, 2015.

\begin{tabular}{|l|l|l|l|l|l|}
\hline \multirow{2}{*}{ No } & \multirow{2}{*}{ Desa Sampel } & \multicolumn{3}{|l|}{ Produksi dan Nilai Produksi Gula Cair } \\
\cline { 3 - 6 } & & \multicolumn{3}{l|}{ Produksi (Kg) } & \multicolumn{2}{l|}{ Nilai Produksi (Rp) } \\
\cline { 3 - 6 } & & Per-UT & Per-Ha & Per-UT & Per-Ha \\
\hline 1. & Alue Rangan & 45,36 & 864,00 & $680.400,00$ & $12.960 .000,00$ \\
2. & Paya Keutapang & 37,70 & 837,78 & $565.500,00$ & $12.566 .666,67$ \\
3. & Sungai Simpang & 48,88 & 850,00 & $733.125,00$ & $12.750 .000,00$ \\
4. & Seuneumbok Pase & 56,55 & 870,00 & $848.250,00$ & $13.050 .000,00$ \\
5 & Alue Itam & 40,60 & 854,75 & $609.000,00$ & $12.821 .052,63$ \\
6 & Bukit Drien & 52,88 & 881,25 & $740.250,00$ & $12.337 .500,00$ \\
7 & Seunumbok Aceh & 32,00 & 800,00 & $480.000,00$ & $12.000 .000,00$ \\
\hline Rata-rata & 44,95 & 856,14 & $665.400,00$ & $12.674 .285,00$ \\
\hline
\end{tabular}

Sumber : Data Primer (diolah), 2015

Tabel IV-9 di atas menunjukkan bahwa rata-rata produksi aren dalam bentuk gula cair adalah 44,95 Kg/UT atau 856,14 Kg/ $\mathrm{Ha}$, dengan harga Rp. $14.000 / \mathrm{Kg}$, maka rata-rata nilai produksinya adalah sebesar Rp. $665.400,00 /$ UT atau Rp. 12.674.285,00/Ha.

Tabel IV-10 : Rata-rata Produksi dan Nilai Produksi Usahatani Aren Bentuk Gula Padat di Kecamatan Sungai Raya, 2015.

\begin{tabular}{|l|l|l|l|l|l|}
\hline \multirow{4}{*}{ No } & \multirow{3}{*}{ Desa Sampel } & \multicolumn{3}{l}{ Produksi dan Nilai Produksi Gula Padat } \\
\cline { 3 - 6 } & & Produksi (Kg) & \multicolumn{2}{l|}{ Nilai Produksi (Rp) } \\
\cline { 3 - 6 } & & Per-UT & Per-Ha & Per-UT & Per-Ha \\
\hline 1. & Alue Rangan & 42,35 & 705,83 & $762.300,00$ & $12.705 .000,00$ \\
2. & Paya Keutapang & 35,00 & 700,00 & $630.000,00$ & $12.600 .000,00$ \\
3. & Sungai Simpang & 40,24 & 619,00 & $724.230,00$ & $11.142 .000,00$ \\
4. & Seuneumbok Pase & 44,17 & 662,50 & $795.000,00$ & $11.925 .000,00$ \\
5 & Alue Itam & 39,00 & 650,00 & $702.000,00$ & $11.700 .000,00$ \\
6 & Bukit Drien & 44,02 & 663,57 & $792.300,00$ & $11.944 .221,11$ \\
7 & Seunumbok Aceh & 36,75 & 700,00 & $661.500,00$ & $12.600 .000,00$ \\
\hline Rata-rata & 41,23 & 668,08 & $742.140,00$ & $12.025 .416,67$ \\
\hline
\end{tabular}

AGRISAMUDRA, Jurnal Penelitian Vol.2 No. 2 Juli-Desember 2015 faktor-faktor produksi. Selain dipengaruhi oleh kualitas penggunaan faktor-faktor produksi, produksi juga sangat dipengaruhi oleh tingkat kombinasi yang tepat antara faktor-faktor produksi yang dilakukan oleh petani. Produksi yang dihasilkan dapat diukur dalam bentuk fisik yaitu dalam kilogram (Kg). Harga gula aren yang berlaku pada saat dilakukan penelitian yaitu sebesar Rp. 14.000/kg gula cair dan Rp. $18.000 / \mathrm{kg}$ gula padat. Untuk mengetahui produksi dan nilai produksi usahatani aren bentuk gula padat dan bentuk gula cair dapat dilihat pada tabel IV-9 sebagai berikut :

Untuk melihat rata-rata produksi dan nilai produksi usahatani aren bentuk gula padat di Kecmatan Sungai Raya Kabupaten Aceh Timur dapat dilihat pada tabel IV-10 berikut: 
Tabel IV-10 di atas menunjukkan bahwa rata-rata produksi aren dalam bentuk padat adalah $41,23 \mathrm{Kg} / \mathrm{UT}$ atau $668,08 \mathrm{Kg} / \mathrm{Ha}$, dengan harga Rp. $18.000 / \mathrm{Kg}$, maka rata-rata nilai produksinya adalah Rp. 742.140,00/UT atau 12.025.416,67/Ha. Dengan perbedaan rata-rata produksi dan nilai produksi gula aren bentuk gula cair dengan bentuk gula padat adalah Rp. $76.740,00 /$ UT dan Rp. 648.864,33/Ha atau $10,34 \%$.

\section{tabel tabel IV-11 berikut:}

Tabel IV-11 : Rata-Rata Pendapatan Usahatani Aren Bentuk Gula Padat dan Bentuk Gula Cair di Kecamatan Sungai Raya,2015

\begin{tabular}{|l|l|l|l|l|l|}
\hline \multirow{2}{*}{ No } & \multirow{4}{*}{ Desa Sampel } & \multicolumn{4}{|l|}{ Pendapatan Bersih (Rp) } \\
\cline { 3 - 6 } & & Gula Cair & Gula Padat \\
\cline { 3 - 6 } & & Per-UT & Per-Ha & Per-UT & Per-Ha \\
\hline 1. & Alue Rangan & $158.720,00$ & $3.023 .238,10$ & $101.200,00$ & $1.686 .666,67$ \\
2. & Paya Keutapang & $81.320,00$ & $1.807 .111,11$ & $38.850,00$ & $777.000,00$ \\
3. & Sungai Simpang & $176.445,00$ & $3.068 .608,70$ & $22.130,00$ & $340.461,54$ \\
4. & Seuneumbok Pase & $244.070,00$ & $3.754 .923,08$ & $97.833,33$ & $1.467 .500,00$ \\
5 & Alue Itam & $112.320,00$ & $2.364 .631,58$ & $56.850,00$ & $947.500,00$ \\
6 & Buket Drien & $161.070,00$ & $2.684 .500,00$ & $87.800,00$ & $1.323 .618,09$ \\
7 & Seunumbok Aceh & $20.820,00$ & $520.500,00$ & $52.900,00$ & $1.007 .619,05$ \\
\hline Rata-rata & $37.053,33$ & $2.610 .539,68$ & $71.790,00$ & 1.163 .263 .05 \\
\hline
\end{tabular}

Sumber : Data Primer (diolah), 2015

Tabel IV-11 di atas menunjukkan bahwa rata-rata pendapatan bersih usahatani aren dalam bentuk gula cair adalah Rp. 37.053,33/UT atau Rp. $2.610 .539,68 / \mathrm{Ha}$, sedangkan rata-rata usahatani aren bentuk gula padat adalah Rp. 71.790,00/UT atau Rp. 1.163.263,05/Ha. Selisih pendapatan usahatani aren bentuk gula cair dengan bentuk gula padat adalah Rp. 34.736,67/UT atau Rp. 1.447.276,63/Ha atau 48,38\%.

\section{Analisis Perbedaan Pendapatan Usahatani Aren Bentuk Gula Cair dan Bentuk Gula Padat.}

Berdasarkan hasil pengolahan data diperoleh hasil bahwa terdapat perbedaan pendapatan usahatani aren bentuk gula cair dengan bentuk gula padat yang disebabkan karena pada gula aren bentuk cair jumlah produksi jauh lebih tinggi dibandingkan bentuk gula padat.

Agar lebih meyakinkan apakah perbedaan tersebut signifikan atau tidak, maka dilakukan pengujian statistik uji " $t$ ". Dari hasil perhitungan perbedaan pendapatan usahatani aren bentuk gula cair dan bentuk gula padat diperoleh $\mathrm{t}$ hitung = 2,816 sedangkan t tabel pada tingkat kepercayaan $95 \%(\alpha=0,05)$ dengan $\mathrm{dk}=14+12-2=24$ adalah 1,710 dan pada tingkat kepercayaan $99 \%$ $(\alpha=0,01)$ dengan $\mathrm{dk}=14+12-2=24$ adalah 2,492 . Ini berarti $t$ hitung $>\mathrm{t}$ tabel baik pada tingkat kepercayaan $95 \%(\alpha=0,05)$ maupun pada tingkat kepercayaan 99\% $\quad(\alpha=0,01)$.

Dengan demikian maka hipotesis Ha diterima dan Ho ditolak. Artinya ada perbedaan pendapatan antara usahatani aren bentuk gula cair dengan bentuk gula padat, yang disebabkan karena

\section{Pendapatan}

Pendapatan dalam penelitian ini adalah pendapatan bersih atau keuntungan. Pendapatan bersih adalah selisih antara nilai produksi (pendapatan kotor) dengan total biaya produksi yang digunakan pada proses produksi bersangkutan.

Besarnya rata-rata pendapatan bersih (keuntungan) pada usahatani aren dalam bentuk gula cair dan bentuk gula padat dapat dilihat pada an

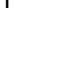


rata produksi tetap adalah Rp. 449.785,71/UT atau Rp. 7.288.194,44/Ha. Sedangkan biaya variabel adalah $\mathrm{Rp}$. 220.571,43/UT atau Rp. 3.574.074,07/Ha Total penggunaan biaya produksi usahatani aren bentuk padat adalah Rp. 670.357,14/UT atau Rp. 10.862.268,52/Ha. Perbedaan penggunaan biaya produksi usahatani aren bentuk gula padat dan bentuk gula cair adalah Rp. 142.010,47/UT dan Rp. $798.522,48 / \mathrm{Ha}$ atau $21,18 \%$.

5. Rata-rata produksi aren dalam bentuk cair adalah 44,95 $\mathrm{Kg} / \mathrm{UT}$ atau $856,14 \mathrm{Kg} / \mathrm{Ha}$, dengan harga Rp. $14.000 / \mathrm{Kg}$, maka rata-rata nilai produksinya adalah sebesar Rp. 665.400,00/UT atau Rp. 12.674.285,00/Ha. Produksi aren dalam bentuk padat adalah $41,23 \mathrm{Kg} / \mathrm{UT}$ atau $668,08 \mathrm{Kg} / \mathrm{Ha}$, dengan harga Rp. $18.000 / \mathrm{Kg}$, maka rata-rata nilai produksinya adalah Rp. 742.140,00/UT atau $12.025 .416,67 / \mathrm{Ha}$. Dengan perbedaan ratarata produksi dan nilai produksi gula aren bentuk gula cair dengan bentuk gula padat adalah Rp. 76.740,00/UT dan Rp. $648.864,33 / \mathrm{Ha}$ atau $10,34 \%$.

6. Rata-rata pendapatan bersih usahatani aren bentuk gula cair adalah Rp. 37.053,33/UT atau Rp. 2.610.539,68/Ha, sedangkan ratarata usahatani aren bentuk gula padat adalah Rp. 71.790,00/UT atau Rp. 1.163.263,05/Ha. Selisih pendapatan usahatani aren bentuk gula cair dengan bentuk gula padat adalah Rp. 34.736,67/UT atau Rp. 1.447.276,63/Ha atau 48,38\%.

7. Dari hasil perhitungan perbedaan pendapatan usahatani aren bentuk gula cair dan bentuk gula padat diperoleh $\mathrm{t}$ hitung $=2,816$ sedangkan $\mathrm{t}$ tabel pada tingkat kepercayaan $95 \%(\alpha=0,05)$ dengan $\mathrm{dk}=14+12-2=24$ adalah 1,710 dan pada tingkat kepercayaan $99 \%(\alpha=0,01)$ dengan $d k=14+12-2=24$ adalah 2,492. Ini berarti t hitung $>\mathrm{t}$ tabel baik pada tingkat kepercayaan 95\% $(\alpha=$ $0,05)$ maupun pada tingkat kepercayaan $99 \%$ $(\alpha=0,01)$. Dengan demikian maka hipotesis Ha diterima dan Ho ditolak. Artinya ada perbedaan pendapatan antara usahatani aren bentuk gula cair dengan bentuk gula padat di Kecamatan Sungai Raya Kabupaten Aceh Timur.

\section{Saran-saran}

a. Dari hasil penelitian menunjukkan bahwa jumlah produksi dan nilai produksi sedikit sekali hanya $10,34 \%$, oleh karena itu disaran bagi para pengusaha untuk meningkatkan jumlah produksi dengan menambah luas lahan produksi agar dapat memperoleh jumlah produksi dan nilai produksi yang tinngi untuk dapat memenuhi kebutuhan pengusaha dan keinginan konsumen.

b. Diharapkan dengan penelitian ini petani dapat memanfaatkan peluang yang optimal dalam menawarkan produksinya sesuai keinginan konsumen.

c. Diharapkan kepada pemerintah atau instansi terkait untuk terus memberikan bimbingan dan penyuluhan kepada petani tentang sistim pengolahan yang baik pada usahatani aren.

d. Untuk menghindari kelangkaan komoditi gula aren atau kurang berminatnya petani, hendaknya pemerintah membuat program peningkatkan produksi dengan cara ektensifikasi pertanian agar lahan usahatani aren bertambah.

\section{DAFTAR PUSTAKA}

Anonimous. 2014, Aceh Timur Dalam Angka, Dinas Kehutanan dan Perkebunan Kabupaten aceh Timur.

Anonymous, 2013. Data Keadaan Luas Lahan, Produksi dan produktivitas Usahatani Aren Kecamatan Sungai Raya, BPP Sungai Raya, Aceh Timur

htpp://www.arengasugar.multiply.com/;di akses 05 Oktober 2014

http://x-jungle.blogspot.com/2008/05/arenarenga-pinnata.html. diakses 21 oktober 2014

Ken Suratiyah, 2006. Ilmu Usahatani, Penebar Swadaya, Jakarta

Mubyarto , 1981. Metode Penelitian Ekonomi, Yayasan Agronomika, Yogyakarta.

Ngangi, 2001. Agroindustri Membangun Bangsa, Rineka Cipta, Jakarta.

Pasaribu, Amudi, 1981. Pengantar Statistik, Ghalia Indonesia, Jakarta.

Saladin, 2003. Marketing, Bumi Aksara, Jakarta

Sudjana, 2005. Teknik Analisa Regresi dan Kolerasi, Tarsito, Bandung.

Soekartawi, 1996. Ilmu Usahatani dan Penelitian Untuk Pengembangan Petani Kecil, Penerbit Universitas Indonesia, Jakarta

Soeseno, Slamet. 1992. Bertanam Aren, Penebar Swadaya, Jakarta

Sugiono, 2012. Metode Penelitian Kuantitatif dan $R \& D$, Alfabeta, Bandung 